\title{
ANALYSIS OF OXYGEN BLOOD SATURATION/ RESPIRATORY RATE INDEX, NEWS2, CURB65, AND QUICK SEQUENTIAL ORGAN FAILURE ASSESSMENT SCORES TO ASSESS PROGNOSIS IN PATIENTS WITH MILD CORONAVIRUS DISEASE 2019
}

\author{
Santiago N. Piombi-Adanza*, María C. Baretto, Flavia A. Echaide, Josefina Arias-Mahiques, \\ Matías Carreras, Eliana Hidalgo-Fredez, luciana M. Vignolo, Noel Parodi, Tomás Domínguez- \\ Monclá, Jimena del V. Carlos, María F. Padula, Santiago Haedo, Mariana Sigman, laura Hermida, \\ María J. Padilla, and Francisco Paulin \\ Internal Medicine Division, Hospital Juan A. Fernández, Buenos Aires, Argentina
}

\begin{abstract}
Background: Hospital bed saturation has been one of the problems to solve during the SARS-CoV-2 pandemic. However, not every patient who is admitted requires close monitoring or specific therapeutics. Mild cases could be managed in the outpatient setting. Objective: Our study aimed to analyze the accuracy of the oxygen saturation/respiratory rate (sat/RR) index, NEWS2, CURB65, and quick Sequential Organ Failure Assessment (qSOFA) scores to predict supplemental oxygen requirement and prolonged hospital stay in patients with mild coronavirus disease 2019 (COVID-19). Methods: A prospective cohort study in an academic medical center. We compared the values of these scores according to the occurrence or not of each outcome. When differences between groups were statistically significant, the discriminatory capacity of the score for that outcome was analyzed. Results: We included 271 patients. Of them, 11.07\% required supplemental oxygen, showing significantly higher values of NEWS2 score and qSOFA score, and lower values of Sat/RR index. About 38\% presented prolonged hospital stay, with significantly higher values of NEWS2 score and lower values of sat/RR index. The ROC curve area under the curve (AUC) of sat/RR index to discriminate the requirement of supplemental oxygen was 0.72 ( $\mathrm{Cl} 95 \% 0.61-0.84)$. The ROC curve of NEWS2 and qSOFA for the same outcome was 0.75 (95\% [95\% Cl 0.65-0.85]) and 0.66 (95\% Cl 0.57-0.76), respectively. The ability of the Sat/RR index to discriminate the requirement of prolonged hospitalization showed an AUC of 0.67 (95\% [95\% Cl 0.600.73]). The NEWS2 score showed an AUC of $0.63(\mathrm{Cl} 95 \%$ 0.56-0.70) for the same outcome. Conclusions: sat/RR index and NEWS2 score have a good capacity to discriminate patients at risk of clinical worsening, being the Sat/RR index simpler and easier to calculate. (REV INVEST CLIN. 2021;73(6):399-407)
\end{abstract}

Key words: COVID-19. Mild. Pneumonia. SARS-CoV-2. Respiratory failure. Prognosis.

*Corresponding author:

Santiago N. Piombi-Adanza

E-mail: santiago.piombi@gmail.com
Received for publication: 25-02-2021

Approved for publication: 05-07-2021

DOI: $10.24875 / R I C .21000120$

0034-8376 / (c) 2021 Revista de Investigación Clínica. Published by Permanyer. This is an open access article under the CC BY-NC-ND license (http://creativecommons.org/licenses/by-nc-nd/4.0/). 


\section{INTRODUCTION}

In December 2019, a new respiratory disease called coronavirus disease 2019 (COVID-19) caused by the severe acute respiratory syndrome (SARSCoV-2) virus appeared in Wuhan, China, and rapidly spread worldwide ${ }^{1}$. By August 7, 18,902,735 cases of COVID-19 had been diagnosed across the world, and 709,511 patients with COVID-19 had died ${ }^{2}$. The Chinese Center for Disease Control and Prevention reported $14 \%$ and $5 \%$ of severe and critical cases, respectively ${ }^{3}$. Compared with other respiratory viruses, the case fatality rate appears to be lower than SARS and the Middle East respiratory syndrome, but higher than influenza ${ }^{4}$. Mild forms of COVID-19 represent the vast majority of cases. Since the risk of unfavorable course of this group of patients is usually low, additional evaluation is generally unnecessary, and cases can be managed in the outpatient setting. However, a minority of these patients with mild disease will subsequently present clinical worsening and may require close monitoring, additional testing, and hospital admission ${ }^{5}$. Tools designed to identify this subgroup of patients are lacking.

Several scores have been proposed to detect patients at risk of clinical deterioration and death in different clinical scenarios. The quick Sequential Organ Failure Assessment (qSOFA) criteria, which consist of respiratory rate (RR), Glasgow Coma Scale, and systolic blood pressure, is a useful tool to predict in-hospital mortality in the general ward ${ }^{6,7}$. The National Early Warning Score (NEWS) consists of seven parameters and was built to improve the early detection of clinical deterioration of critically ill patients ${ }^{8}$. NEWS has equivalent or superior accuracy compared with qSOFA to predict clinical deterioration in infected patients outside the intensive care unit (ICU $)^{9,10}$. During the pandemic, the patient's age was added to the score as a new parameter based on the first observations made in China, which pointed that age is an important prognostic factor in this disease. The CURB-65 was developed for the evaluation of patients with community-acquired pneumonia (CAP) and includes newonset confusion, urea levels, RR, blood pressure $\mathrm{mmHg}$, and age ${ }^{11}$. It has been validated to predict 30-day mortality in CAP ${ }^{12}$. Patients with a low score risk $(0-1)$ can be managed as outpatients since they are considered to have low-risk pneumonia ${ }^{13,14}$.
To date, there are no validated scores to predict the evolution of mild forms of COVID-19. Early recognition of patients who could be managed in the outpatient setting is important to avoid health-care system saturation. Furthermore, the identification of those patients who will require close monitoring is crucial. The utilization of scores as qSOFA, NEWS2, and CURB-65, which have proven to be useful in different clinical scenarios, appears as an interesting option.

Given that in the initial phase, COVID-19 mainly affects the respiratory system with minor damage to other organs, we hypothesized that an index composed only by respiratory parameters could detect patients at risk of clinical worsening with more preci$\operatorname{sion}^{15}$. As a consequence, we studied the blood oxygen saturation/RR index (sat/RR). This adaptation of the ROX index applied to patient's breathing room air was chosen because of its simplicity to measure them, and the replicability between different observers. Our study aimed to analyze the accuracy of sat/ RR, NEWS2, CURB65, and qSOFA scores to predict the development of supplemental oxygen requirement and prolonged hospital stay in patients with mild COVID-19.

\section{METHODS}

We conducted a prospective cohort study in Fernandez Hospital, an academic medical center located in Buenos Aires, Argentina, between April 24 and June 2. During that period, every patient admitted to the hospital was included. The criteria for being admitted to the hospital were the presence of COVID-19 pneumonia and COVID-19 infection with comorbidities and risk factors, with or without pneumonia. SARS-CoV-2 infection was defined as a positive RT-PCR assay in a nasopharyngeal swab. The mildness of the disease was defined at admission, based on pulse oximetry greater than $92 \%$ and a RR lower than 30 breaths per minute with no supplemental oxygen requirement. There were no exclusion criteria.

The diagnosis of pneumonia was defined as the presence of clinical signs and symptoms compatible with lower airway infection (cough, dyspnea, and fever) with image confirmation. The techniques used included chest X-ray, chest ultrasound, and/or chest CT scan. 
Data were collected in a structured form during the patients' admission, including demographic and epidemiological information, comorbidities (diabetes, obesity, hypertension, congestive heart failure, coronary disease, HIV infection, chronic kidney disease, alcohol abuse, smoking history, chronic obstructive pulmonary disease, asthma, and tuberculosis), signs and symptoms at disease onset, vital signs (blood pressure, heart and RR, temperature, and blood oxygen saturation by pulse oximetry), qSOFA, CURB65, NEWS2, sat/RR scores, blood test, and chest image. A member of the data management team, reviewed by a second member of the same team, loaded data submitted by physicians on the paper form to a digital database.

Patients were followed until hospital discharge, ICU admission, or death. The primary outcome was the accuracy of sat/RR, NEWS2, CURB65, and qSOFA to predict the development of supplemental oxygen requirement. The secondary outcome was the accuracy of these scores to predict prolonged hospitalization (defined as greater than 10 days since admission).

\section{Statistical analysis}

Comparisons between groups were made with a ttest or Mann-Whitney test, depending on the presence or not of normal distribution. When differences between groups were statistically significant, the discriminatory capacity of the score for that outcome was analyzed with the receiver operating curve $(R O C)$. The area under the curve (AUC) and their $95 \% \mathrm{Cl}$ were informed. A cutoff point was defined according to the values of the ROC curve, and univariate and multivariate logistic regression was performed. ORs and their $95 \% \mathrm{Cl}$ were reported. We analyzed the correlation between Sat/RR index and C-reactive protein (CRP) at admission using Spearman's method. The manuscript was written according to the STROBE initiative for the communication of observational studies. The Institutional Ethics Committee of our hospital reviewed and approved the study.

\section{RESULTS}

We included 271 patients. The general characteristics of the cohort are shown in Table 1. The mean (SD) of age was 42 (16) years; $46.83 \%$ of patients were female, and $48 \%$ had the diagnosis of pneumonia at admission. Regarding comorbidities, $43.25 \%$ had at least one condition, with obesity as the most frequent $(18.7 \%)$, followed by hypertension $(12.7 \%)$ and diabetes (10.7\%). The median (IQR) since the beginning of symptoms was 4 days (2-7). The most prevalent symptom was cough ( $57.14 \%$ ), followed by fever $(55.16 \%)$ and headache (53.7\%). As the cohort included only patients with mild forms of COVID-19, no patients had low oxygen saturation at admission. We analyzed the behavior of four severity scores: sat/RR index, NEWS2, CURB65, and qSOFA. At admission, the mean (SD) of the sat/RR index was 5.19 (1.05); the median (IQR) of NEWS2 score was 2 (1-4); the median (IQR) of CURB65 was 1 (1-2), and the median (IQR) of the qSOFA was $0(0-1)$. In their evolution, 30 patients $(11.07 \%)$ received supplemental oxygen, 9 (3.57\%) required ICU admission, and 107 (38\%) required prolonged hospitalization (longer than 10 days). No patient died during the follow-up. The median (IQR) days of hospitalization was 9 (5-11).

We compared the values of these four scores between the groups of patients that required supplemental oxygen with those who did not. The first group had significantly higher values of NEWS2 score and qSOFA score, and significantly lower values of Sat/RR index (Table 2). When we compared patients that required a prolonged hospitalization from those who did not, the first group had significantly higher values of NEWS2 score and significantly lower values of Sat/RR index (Table 3).

We analyzed the ability to discriminate the occurrence of both outcomes with the ROC curve in those scores that showed significantly different values between groups in the above-mentioned comparison. The AUC of the Sat/RR index to discriminate the requirement of supplemental oxygen in the evolution was $0.72(95 \% \mathrm{Cl} 0.61-0.84)$ (Fig. 1). A cutoff point of 4.5 showed a sensitivity of $79.2 \%$ and a specificity of $57.1 \%$. The same cutoff point showed an OR of 4.61 ( $95 \% \mathrm{Cl} 2.1-10.13$ ). After adjusting to age, obesity, and diabetes, we obtained an OR of 4.77 (95\% $\mathrm{Cl}$ 2.04-11.15). We analyzed the ROC curve of the NEWS2 and the qSOFA score for the same outcome. The AUCs were $0.75(95 \% \mathrm{Cl} 0.65-0.85)$ and 0.66 (95\% Cl 0.57-0.76), respectively. 
Table 1. General characteristics of the study population admitted to Hospital Fernández between April 24 and June 2

\begin{tabular}{|c|c|c|c|}
\hline Variable & $n=271$ & $\begin{array}{l}\text { Respiratory failure } \\
\quad(n=30)\end{array}$ & $\begin{array}{l}\text { Prolonged length of stay } \\
\qquad(n=107)\end{array}$ \\
\hline $\begin{array}{l}\text { Sex, female } \\
\mathrm{n}(\%)\end{array}$ & $\begin{array}{c}128 \\
(47.23 \%)\end{array}$ & $\begin{array}{l}15 \\
(50 \%)\end{array}$ & $\begin{array}{c}49 \\
(45.79 \%)\end{array}$ \\
\hline $\begin{array}{l}\text { Age, } \\
\text { mean (SD) }\end{array}$ & $\begin{array}{l}43.18 \\
(16.9)\end{array}$ & $\begin{array}{l}54.4 \\
(12.5)\end{array}$ & $\begin{array}{l}49.0 \\
(16.9)\end{array}$ \\
\hline \multicolumn{4}{|l|}{ Comorbidities } \\
\hline $\begin{array}{l}\text { At least } 1 \text { comorbidity, } \\
\mathrm{n}(\%)\end{array}$ & $\begin{array}{c}120 \\
(44.25 \%)\end{array}$ & $\begin{array}{c}19 \\
(63.33 \%)\end{array}$ & $\begin{array}{c}59 \\
(55.14 \%)\end{array}$ \\
\hline $\begin{array}{l}\text { Diabetes, } \\
\text { n (\%) }\end{array}$ & $\begin{array}{c}33 \\
(12.18 \%)\end{array}$ & $\begin{array}{c}8 \\
(38.09 \%)\end{array}$ & $\begin{array}{c}21 \\
(19.63 \%)\end{array}$ \\
\hline $\begin{array}{l}\text { Obesity, } \\
\text { n (\%) }\end{array}$ & $\begin{array}{c}55 \\
(20.37 \%)\end{array}$ & $\begin{array}{c}7 \\
(33.33 \%)\end{array}$ & $\begin{array}{c}27 \\
(25.23 \%)\end{array}$ \\
\hline $\begin{array}{l}\text { HIV, } \\
\text { n (\%) }\end{array}$ & $\begin{array}{c}3 \\
(1,19 \%)\end{array}$ & $\begin{array}{c}1 \\
(4.76 \%)\end{array}$ & $\begin{array}{c}3 \\
(2.8 \%)\end{array}$ \\
\hline $\begin{array}{l}\text { Chronic kidney disease, } \\
\text { n (\%) }\end{array}$ & $\begin{array}{c}4 \\
(1.48 \%)\end{array}$ & $\begin{array}{c}1 \\
(3.33 \%)\end{array}$ & $\begin{array}{c}4 \\
(3.74 \%)\end{array}$ \\
\hline $\begin{array}{l}\text { Asthma, } \\
\mathrm{n}(\%)\end{array}$ & $\begin{array}{c}15 \\
(5,95 \%)\end{array}$ & 0 & $\begin{array}{c}6 \\
(5.61 \%)\end{array}$ \\
\hline $\begin{array}{l}\text { Arterial hypertension, } \\
\mathrm{n}(\%)\end{array}$ & $\begin{array}{c}39 \\
(14.39 \%)\end{array}$ & $\begin{array}{c}8 \\
(26.67 \%)\end{array}$ & $\begin{array}{c}26 \\
(24.30 \%)\end{array}$ \\
\hline $\begin{array}{l}\text { COPD, } \\
\text { n (\%) }\end{array}$ & $\begin{array}{c}1 \\
(0,37 \%)\end{array}$ & 0 & $\begin{array}{c}1 \\
(0.93 \%)\end{array}$ \\
\hline $\begin{array}{l}\text { Smoking history, } \\
\mathrm{n}(\%)\end{array}$ & $\begin{array}{c}28 \\
(10.33 \%)\end{array}$ & $\begin{array}{c}5 \\
(16.67 \%)\end{array}$ & $\begin{array}{c}10 \\
(9.35 \%)\end{array}$ \\
\hline $\begin{array}{l}\text { Hepatic disease, } \\
\text { n (\%) }\end{array}$ & $\begin{array}{c}2 \\
(0.74 \%)\end{array}$ & $\begin{array}{c}1 \\
(3.33 \%)\end{array}$ & $\begin{array}{c}2 \\
(1.87 \%)\end{array}$ \\
\hline \multicolumn{4}{|l|}{ Symptoms } \\
\hline $\begin{array}{l}\text { Cough, } \\
\text { n (\%) }\end{array}$ & $\begin{array}{c}158 \\
(58.30 \%)\end{array}$ & $\begin{array}{l}21 \\
(70 \%)\end{array}$ & $\begin{array}{c}66 \\
(61.68 \%)\end{array}$ \\
\hline $\begin{array}{l}\text { Fever, } \\
\text { n (\%) }\end{array}$ & $\begin{array}{c}154 \\
(56.83 \%)\end{array}$ & $\begin{array}{c}22 \\
(73.33)\end{array}$ & $\begin{array}{c}67 \\
(62.62 \%)\end{array}$ \\
\hline $\begin{array}{l}\text { Headache, } \\
\text { n (\%) }\end{array}$ & $\begin{array}{c}143 \\
(52,77 \%)\end{array}$ & $\begin{array}{c}14 \\
(46.67 \%)\end{array}$ & $\begin{array}{c}46 \\
(42.99 \%)\end{array}$ \\
\hline $\begin{array}{l}\text { Asthenia } \\
\mathrm{n}(\%)\end{array}$ & $\begin{array}{c}116 \\
(42.80 \%)\end{array}$ & $\begin{array}{c}11 \\
(36.67 \%)\end{array}$ & $\begin{array}{c}43 \\
(40.19 \%)\end{array}$ \\
\hline $\begin{array}{l}\text { Anosmia/dysgeusia, } \\
\text { n (\%) }\end{array}$ & $\begin{array}{c}89 \\
(33.84 \%)\end{array}$ & $\begin{array}{c}7 \\
(23.33 \%)\end{array}$ & $\begin{array}{c}27 \\
(26.21 \%)\end{array}$ \\
\hline $\begin{array}{l}\text { Myalgia, } \\
\text { n (\%) }\end{array}$ & $\begin{array}{c}89 \\
(32.84 \%)\end{array}$ & $\begin{array}{c}11 \\
(36.67 \%)\end{array}$ & $\begin{array}{c}30 \\
(28.04 \%)\end{array}$ \\
\hline $\begin{array}{l}\text { Sore throat, } \\
\mathrm{n}(\%)\end{array}$ & $\begin{array}{c}86 \\
(31.73 \%)\end{array}$ & $\begin{array}{c}8 \\
(26.67 \%)\end{array}$ & $\begin{array}{c}27 \\
(25.23 \%)\end{array}$ \\
\hline $\begin{array}{l}\text { Dyspnea, } \\
\text { n (\%) }\end{array}$ & $\begin{array}{c}75 \\
(27.68 \%)\end{array}$ & $\begin{array}{c}16 \\
(53.33 \%)\end{array}$ & $\begin{array}{c}41 \\
(38.32 \%)\end{array}$ \\
\hline $\begin{array}{l}\text { Diarrhea, } \\
\text { n (\%) }\end{array}$ & $\begin{array}{c}41 \\
(15.13 \%)\end{array}$ & $\begin{array}{c}5 \\
(16.67 \%)\end{array}$ & $\begin{array}{c}17 \\
(15.89 \%)\end{array}$ \\
\hline $\begin{array}{l}\text { Vomits, } \\
\text { n (\%) }\end{array}$ & $\begin{array}{c}15 \\
(5,54 \%)\end{array}$ & 0 & $\begin{array}{c}6 \\
(5.61 \%)\end{array}$ \\
\hline
\end{tabular}


Table 1. General characteristics of the study population admitted to Hospital Fernández between April 24 and June 2 (continued)

\begin{tabular}{|c|c|c|c|}
\hline Variable & $n=271$ & $\begin{array}{l}\text { Respiratory failure } \\
\quad(n=30)\end{array}$ & $\begin{array}{l}\text { Prolonged length of stay } \\
\qquad(n=107)\end{array}$ \\
\hline \multicolumn{4}{|l|}{ Physical exam } \\
\hline $\begin{array}{l}\text { Systolic blood pressure, } \\
\text { mean (SD) }\end{array}$ & $\begin{array}{l}120 \\
(17.46)\end{array}$ & $\begin{array}{l}123.4 \\
(13.7)\end{array}$ & $\begin{array}{l}123.0 \\
(13.7)\end{array}$ \\
\hline $\begin{array}{l}\text { Diastolic blood pressure, } \\
\text { mean (SD) }\end{array}$ & $\begin{array}{l}75.13 \\
(10.28)\end{array}$ & $\begin{array}{r}75.16 \\
(9.1)\end{array}$ & $\begin{array}{l}75.67 \\
(10.0)\end{array}$ \\
\hline $\begin{array}{l}\text { Heart rate, } \\
\text { mean (DS) }\end{array}$ & $\begin{array}{l}90.33 \\
(13.85)\end{array}$ & $\begin{array}{c}97 \\
(14.8)\end{array}$ & $\begin{array}{l}92.2 \\
(14.9)\end{array}$ \\
\hline $\begin{array}{l}\text { Respiratory rate, } \\
\text { mean (SD) }\end{array}$ & $\begin{array}{l}19.41 \\
(3.75)\end{array}$ & $\begin{array}{l}22.3 \\
(4.2)\end{array}$ & $\begin{array}{l}20.6 \\
(3.7)\end{array}$ \\
\hline $\begin{array}{l}\text { Temperature, } \\
\text { mean (SD) }\end{array}$ & $\begin{array}{l}36,7 \\
(0,95)\end{array}$ & $\begin{array}{l}37.3 \\
(1.2)\end{array}$ & $\begin{array}{l}36.9 \\
(1.0)\end{array}$ \\
\hline $\begin{array}{l}\text { Blood oxygen saturation, } \\
\text { mean (SD) }\end{array}$ & $\begin{array}{l}96.8 \\
(1.38)\end{array}$ & $\begin{array}{l}96 \\
(1.4)\end{array}$ & $\begin{array}{l}96.2 \\
(1.4)\end{array}$ \\
\hline \multicolumn{4}{|l|}{ Biomarkers } \\
\hline $\begin{array}{l}\text { CRP on admission, } \\
\text { median (IQR) }\end{array}$ & $\begin{array}{c}2,6 \\
(0.71-5.7)\end{array}$ & $\begin{array}{c}7.9 \\
(4.7-14.1)\end{array}$ & $\begin{array}{c}4.3 \\
(2.3-8.38)\end{array}$ \\
\hline $\begin{array}{l}\text { LDH on admission, } \\
\text { median (IQR) }\end{array}$ & $\begin{array}{c}238.5 \\
(195-294)\end{array}$ & $\begin{array}{c}333.0 \\
(251.5-410.5)\end{array}$ & $\begin{array}{c}254.5 \\
(206-335)\end{array}$ \\
\hline $\begin{array}{l}\text { Ferritin at } 4^{\text {th }} \text { day, } \\
\text { median (IQR) }\end{array}$ & $\begin{array}{c}380 \\
(138-687)\end{array}$ & $\begin{array}{c}698.8 \\
(375.0-803.0)\end{array}$ & $\begin{array}{c}460.7 \\
(218-919)\end{array}$ \\
\hline $\begin{array}{l}\text { D-dimer at } 4^{\text {th }} \text { day, } \\
\text { median (IQR) }\end{array}$ & $\begin{array}{c}251.5 \\
(224-354)\end{array}$ & $\begin{array}{c}368.0 \\
(265.0-642.0)\end{array}$ & $\begin{array}{c}414.9 \\
(105-1900)\end{array}$ \\
\hline $\begin{array}{l}\text { Absolute lymphocytes count, } \\
\text { (SD) }\end{array}$ & $\begin{array}{l}1606 \\
(781.1)\end{array}$ & $\begin{array}{l}1360.7 \\
(716.8)\end{array}$ & $\begin{array}{l}1527.3 \\
(692.0)\end{array}$ \\
\hline \multicolumn{4}{|l|}{ Clinical evolution } \\
\hline $\begin{array}{l}\text { Supplemental oxygen } \\
\text { requirement (\%) }\end{array}$ & $\begin{array}{c}30 \\
(11.07)\end{array}$ & & \\
\hline $\begin{array}{l}\text { Assisted mechanical } \\
\text { ventilation, } \\
\mathrm{n}(\%)\end{array}$ & $\begin{array}{c}4 \\
(1.75 \%)\end{array}$ & & \\
\hline $\begin{array}{l}\text { Extended hospitalization, } \\
\mathrm{n}(\%)\end{array}$ & $\begin{array}{c}107 \\
(39.48 \%)\end{array}$ & & \\
\hline $\begin{array}{l}\text { Hospital length (days), } \\
\text { median (IQR) }\end{array}$ & $\begin{array}{c}9 \\
(5-11)\end{array}$ & & \\
\hline Death, n (\%) & 0 & & \\
\hline
\end{tabular}

COPD: Chronic Obstructive Pulmonary Disease; CRP: C-reactive protein; HIV: Human Immunodeficiency Virus; LDH: lactate dehydrogenase.

The ability of the Sat/RR index to discriminate the requirement of prolonged hospitalization showed an AUC of 0.67 (95\% Cl 0.60-0.73) (Fig. 2). A cutoff point of 4.5 showed a sensitivity of $82.5 \%$ and a specificity of $35.5 \%$. The same cutoff point showed an OR of 2.46 ( $95 \% \mathrm{Cl} 1.4-4.28)$. After adjusting for age, obesity, and diabetes, we obtained an OR of 2.22 (95\% Cl 1.23-4.01). We analyzed the ROC curve of the NEWS2 score for the same outcome. The AUC was $0.63(95 \% \mathrm{Cl} 0.56-0.70)$.

Those patients with prolonged length of stay presented a mean (SD) of 5.63 days (2.77) since the onset of symptoms at hospital admission compared with a mean (SD) of 4.4 (2.78) from those who did not, with a significant $p$-value $(p=0.007)$. Likewise, 
Table 2. Comparison of scores values regarding the outcome supplemental oxygen requirement

\begin{tabular}{lccc}
\hline Variable & $\begin{array}{c}\text { No supplemental oxygen } \\
\text { requirement }\end{array}$ & $\begin{array}{c}\text { Supplemental oxygen } \\
\text { requirement }\end{array}$ & p-value \\
\hline $\begin{array}{l}\text { NEWS2m, } \\
\text { median (iqr) }\end{array}$ & 2 & 5 & $<0.0001$ \\
CURB65, & $(1-4)$ & $(2.5-5.5)$ & 0.7324 \\
median (iqr) & 1 & 1 & 0.0004 \\
qSOFA, & $(1-1)$ & $(1-2)$ & \\
median (iqr) & 0 & 1 & 0.0001 \\
$\begin{array}{l}\text { Sat/RR, } \\
\text { mean (SD) }\end{array}$ & $(0-1)$ & $(0-1)$ & \\
\hline
\end{tabular}

Table 3. Comparison of scores values regarding the outcome prolonged hospitalization

\begin{tabular}{lccc}
\hline Variable & $\begin{array}{c}\text { No prolonged hospital } \\
\text { stay }\end{array}$ & $\begin{array}{c}\text { Prolonged hospital } \\
\text { stay }\end{array}$ & p-value \\
\hline $\begin{array}{l}\text { NEWS2m, } \\
\text { median (iqr) }\end{array}$ & 2 & 3 & 0.0002 \\
CURB65, & $(1-3)$ & $(2-4)$ & 0.0418 \\
median (iqr) & 1 & 1 & 0.0921 \\
$\begin{array}{l}\text { qSOFA, } \\
\text { median (iqr) }\end{array}$ & $(1-1)$ & $(1-2)$ & \\
Sat/RR, & 0 & 0 & $<0.0001$ \\
mean (SD) & $(0-1)$ & $(0-1)$ & $(0.83)$ \\
\hline
\end{tabular}

patients who developed supplemental oxygen requirements had a mean (SD) of 6.68 (2.98) days from the onset of the symptoms at admission against 4.71 (2.73) from those who did not, with a significant relationship ( $p=0.009$ ).

Regarding the correlation of Sat/RR with RCP at admission, we found an $r$-value of $-0.44(p<0.001)$.

\section{DISCUSSION}

Our study shows that sat/RR index and NEWS2 are useful tools to predict the unfavorable evolution of patients with mild forms of COVID-19. We also found a correlation between days since the onset of symptoms at admission and outcomes.

In our current situation, rapid and accurate identification of patients at risk of having an unfavorable evolution is important since it could help to provide close monitoring and early medical attention to those patients who require it, and manage the cases with a good prognosis in the outpatient setting.

Many studies have proven the prognostic value of either epidemiological or biological factors. In regard to epidemiology, age and some comorbidities as arterial hypertension, diabetes, obesity, malignancy, and pulmonary disease have shown to be associated with poor outcomes ${ }^{16-18}$. Similarly, the alteration of some biological markers such as the elevation of CRP, interleukin-6, lactate dehydrogenase, and D-dimer, or the presence of lymphocytopenia or thrombocytopenia has shown a correlation with an unfavorable evolution $^{19-21}$. Likewise, we found a good correlation between Sat/RR index and RCP levels at admission, showing that the index varies in relationship with the degree of inflammation.

Although the prognostic value of all the previously mentioned variables has been well documented, information about them is scarce in mild COVID-19 cases. Cases that initially present as mild COVID-19 
Figure 1. Blood oxygen saturation/respiratory rate index ROC curve for the outcome supplemental oxygen requirement.

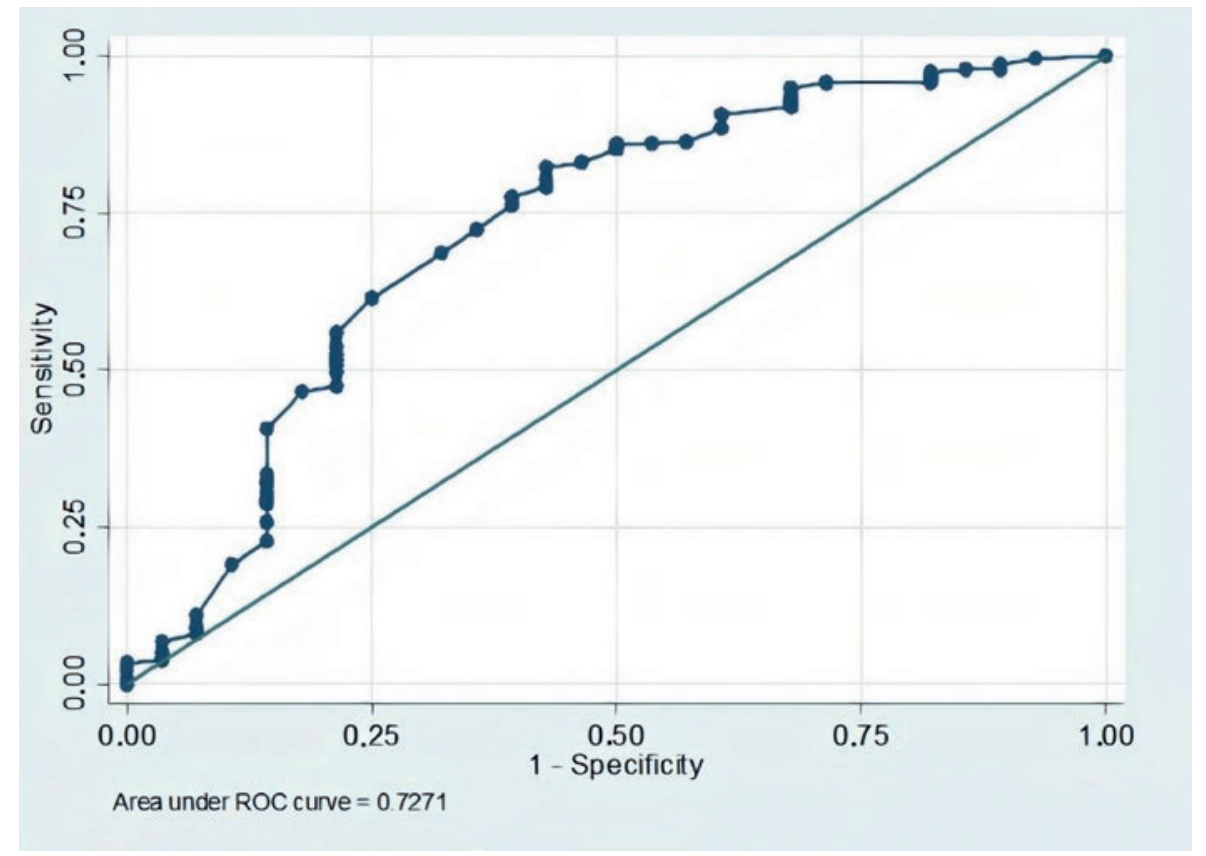

Figure 2. Blood oxygen saturation/respiratory rate index ROC curve for the outcome prolonged hospitalization.

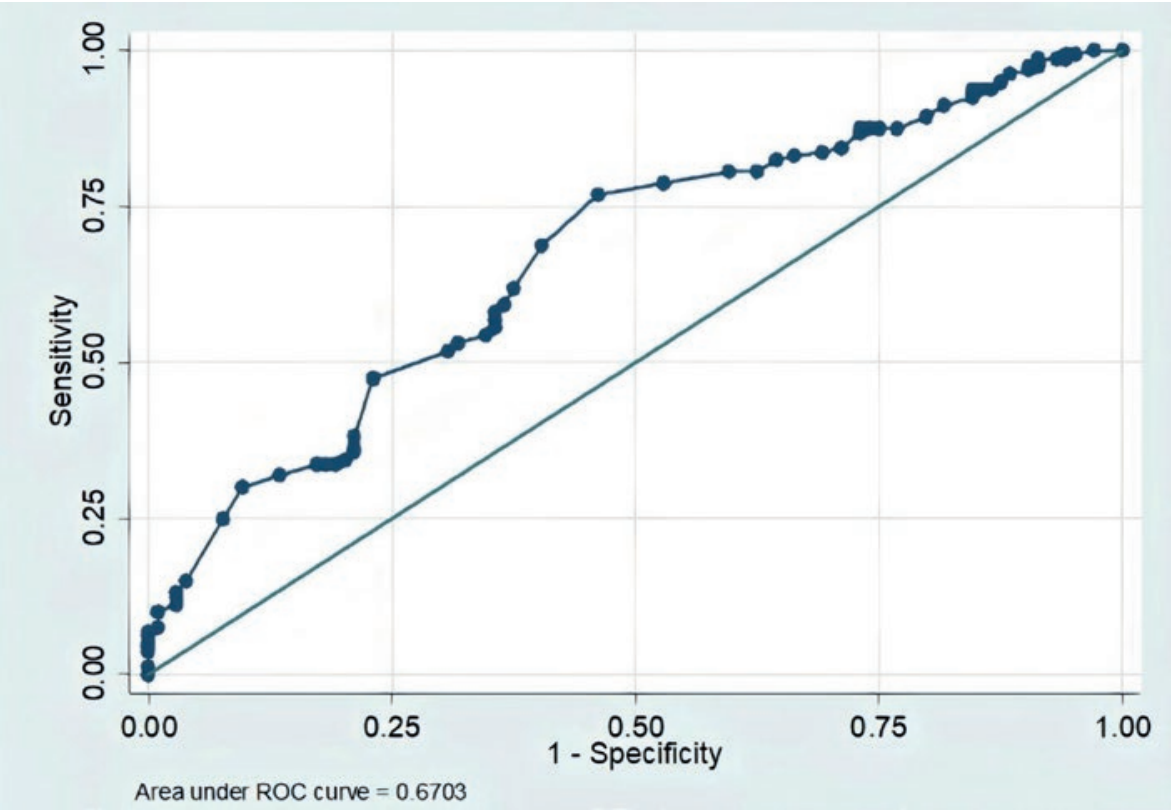

represent a clinical scenario that has received less attention from researchers than the severe forms of the disease. As a consequence, our ability to predict the clinical course of these patients is limited.

The clinical spectrum of mild COVID-19 has a wide range of symptoms. An observational study carried out in Europe that included 1420 patients with mildmoderate COVID-19 showed that the most prevalent symptoms were headache, anosmia, nasal obstruction, cough, myalgia, rhinorrhea, dysgeusia, and sore throat. Most of these patients do not require hospital admission since they can be managed at their homes. According to $\mathrm{WHO}$, as long as the case is mild or 
moderate without risk factors for severe disease, the household is suitable for isolation. If monitoring for signs of deterioration is feasible, home care could be carried out ${ }^{22}$. However, the utilization of a simple prognostic score built with variables obtained in the physical exam could be very useful to complete the prognostic information provided by the previously mentioned demographic and clinical data. This background supported our intention to study the qSOFA, CURB65, and NEWS2 scores in mild COVID-19. Furthermore, it highlights the importance of the identification of SatO2/RR index as a simple prognostic tool. We included in that index only variables that evaluate the respiratory system because it is the mainly affected system in the initial phase of the disease. On the other side, systemic compromise and organ failure usually develops in patients with severe and advanced disease, generally admitted in ICU1. The selection of these variables is supported by studies that show that RR and blood oxygen saturation (SatO2) are more frequently affected than other vital signs ${ }^{23,24}$. Moreover, there are reported cases in which patients show no change in physical exam parameters except for an increased RR and low blood oxygen saturation. This clinical picture has been called silent pneumonia or silent hypoxemia ${ }^{25}$. As the case report mentions, the patients' vital signs were all normal except those which this index takes into account.

When we reviewed the available literature, we found an antecedent to the SatO2/RR index, the ROX in$\mathrm{dex}^{26,27}$. That index is composed of three variables: SatO2, RR, and the fraction of inspired oxygen (FiO2). It is used in patients receiving oxygen by high-flow nasal cannula as a tool to predict its failure and determine if early intubation is needed. The sat/ RR index is simpler but can be applied only in patients without supplemental oxygen, as occurs in mild COVID-19.

Our study has points that stand out. First, it focuses on patients with mild COVID-19, a frequent clinical scenario in which there are still many gaps to reveal. Second, a useful and simple tool to evaluate these patients is proposed. Third, the study has a prospective cohort design, minimizing the possibility of selection bias. Fourth, the use of a jointed index may detect patients at risk who have both $\mathrm{RR}$ and $\mathrm{SaO}_{2}$ in normal ranges, and otherwise, would not be correctly assessed. However, it is not exempted from limitations. First, the fact that important outcomes such as death or ICU admission were scarce made their evaluation difficult. Second, even though the patients were followed up to hospital discharge and no patient was lost, a subsequent follow-up was not done, making it impossible to know whether readmission occurred. Third, numerous factors influence pulse oximetry results such as altitude, age, and obesity among others, deeming it not accurate in such scenarios. Finally, this study was conducted in a single center, which attempts against its external validity.

We consider that the sat/RR index has a good capacity to discriminate those patients at risk of presenting clinical worsening from those who will not. That capacity is similar to one of the most used scores (NEWS2) with the advantage of being simpler. As a consequence, we believe this index could be a meaningful contribution to the management of mild COVID-19 patients. Nevertheless, these findings should be confirmed with new studies, ideally with a multicenter design.

\section{REFERENCES}

1. Zhou F, Yu T, Du R, Fan G, Liu Y, Liu Z, et al. Clinical course and risk factors for mortality of adult inpatients with COVID-19 in Wuhan, China: a retrospective cohort study. Lancet. 2020; 395:1054-62.

2. WHO Situation Report 200-Coronavirus Disease (COVID-19). Available from: https://www.who.int/docs/default-source/ coronaviruse/situation-reports/20200807-covid-19-sitrep-200.pdf?sfvrsn=2799bc0f_2.

3. Wu Z, McGoogan JM. Characteristics of and important lessons from the coronavirus disease 2019 (COVID-19) outbreak in China: summary of a report of 72314 cases from the Chinese center for disease control and prevention. JAMA. 2020;323:1239-42.

4. Rajgor DD, Lee MH, Archuleta S, Bagdasarian N, Quek SC. The many estimates of the COVID-19 case fatality rate. Lancet Infect Dis. 2020;20:776-7.

5. Gandhi RT, Lynch JB, Del Rio C. Mild or moderate Covid-19. N Engl ] Med. 2020;383:1757-66.

6. Freund $\mathrm{Y}$, Lemachatti $\mathrm{N}$, Krastinova $\mathrm{E}$, Van Laer $\mathrm{M}$, Claessens $\mathrm{YE}$, Avondo A, et al, French Society of Emergency Medicine Collaborators Group. Prognostic accuracy of sepsis- 3 criteria for inhospital mortality among patients with suspected infection presenting to the emergency department. JAMA. 2017;317:301-8.

7. Raith EP, Udy AA, Bailey M, McGloughlin S, Maclsaac C, Bellomo $\mathrm{R}$, et al, Australian and New Zealand Intensive Care Society (ANZICS) Centre for Outcomes and Resource Evaluation (CORE). Prognostic accuracy of the SOFA score, SIRS criteria, and qSOFA Score for in-hospital mortality among adults with suspected infection admitted to the intensive care unit. JAMA. 2017;317:290-300

8. McGinley A, Pearse RM. A national early warning score for acutely ill patients. BMJ. 2012;345:e5310.

9. Goulden R, Hoyle MC, Monis J, Railton D, Riley V, Martin P, et al. qSOFA, SIRS and NEWS for predicting inhospital mortality and ICU admission in emergency admissions treated as sepsis. Emerg Med J. 2018;35:345-9.

10. Churpek MM, Snyder A, Han X, Sokol S, Pettit N, Howell MD, et al. Quick sepsis-related organ failure assessment, systemic inflammatory response syndrome, and early warning scores for detecting clinical deterioration in infected patients outside 
the intensive care unit. Am J Respir Crit Care Med. 2017; 195:906-11.

11. Lim WS, van der Eerden MM, Laing R, Boersma WG, Karalus N, Town $\mathrm{Gl}$, et al. Defining community acquired pneumonia severity on presentation to hospital: an international derivation and validation study. Thorax. 2003;58:377-82.

12. Chalmers JD, Singanayagam A, Akram AR, Mandal P, Short PM, Choudhury G, et al. Severity assessment tools for predicting mortality in hospitalised patients with community-acquired pneumonia. Systematic review and meta-analysis. Thorax. 2010;65:878-83.

13. Lim WS, Baudouin SV, George RC, Hill AT, Jamieson C, Le Jeune I, et al, Pneumonia Guidelines Committee of the BTS Standards of Care Committee. BTS guidelines for the management of community acquired pneumonia in adults: update 2009. Thorax. 2009;64:iii 1-55.

14. Metlay JP, Waterer GW, Long AC, Anzueto A, Brozek J, Crothers $\mathrm{K}$, et al. Diagnosis and treatment of adults with communityacquired pneumonia. An official clinical practice guideline of the American thoracic society and infectious diseases society of America. Am J Respir Crit Care Med. 2019;200:e45-67.

15. Li X, Ma X. Acute respiratory failure in COVID-19: is it "Typical" ARDS? Crit Care. 2020;24:198

16. Wang D, Hu B, Hu C, Zhu F, Liu X, Zhang J, et al. Clinical characteristics of 138 hospitalized patients with 2019 novel coronavirus-infected pneumonia in Wuhan, China. JAMA. 2020;323: 1061-9.

17. Huang C, Wang Y, Li X, Ren L, Zhao J, Hu Y, et al. Clinical features of patients infected with 2019 novel coronavirus in Wuhan, China. Lancet. 2020;395:497-506.

18. Yang J, Zheng Y, Gou X, Pu K, Chen Z, Guo Q, et al. Prevalence of comorbidities and its effects in patients infected with SARSCoV-2: a systematic review and meta-analysis. Int J Infect Dis. 2020;94:91-5
19. Kermali M, Khalsa RK, Pillai K, Ismail Z, Harky A. The role of biomarkers in diagnosis of COVID-19-a systematic review. Life Sci. 2020;254:117788.

20. Thirumalaisamy PV, Christian GM. Mild versus severe COVID-19: laboratory markers. Int J Infect Dis. 2020;95:304-7.

21. Eastin C, Eastin T. Clinical characteristics of coronavirus disease 2019 in China. N Engl J Med. 2020;382:1708-20.

22. World Health Organization. Home Care for Patients with Suspected or Confirmed COVID-19 and Management of Their Contacts. Interim Guidance; 2020. Available from: https://www. who.int/publications-detail/home-care-for-patients-with-suspected-novel-coronavirus-(ncov)-infection-presenting-withmild-symptoms-and-management-of-contacts. [Last accessed on 2020 Aug 25].

23. Jang JG, Hur J, Hong KS, Lee W, Ahn JH. Prognostic accuracy of the SIRS, qSOFA, and NEWS for early detection of clinical deterioration in SARS-CoV-2 infected patients. J Korean Med Sci. 2020;35:e234

24. Myrstad $M$, Ihle-Hansen $H$, Tveita AA, Andersen EL, Nygård $S$, Tveit A, et al. National early warning score 2 (NEWS2) on admission predicts severe disease and in-hospital mortality from Covid-19-a prospective cohort study. Scand J Trauma Resusc Emerg Med. 2020;28:66.

25. Ottestad W, Seim M, Mæhlen JO. COVID-19 with silent hypoxemia. Tidsskr Nor Laegeforen. 2020:140:299.

26. Roca O, Messika J, Caralt B, García-de-Acilu M, Sztrymf B, Ricard $\mathrm{JD}$, et al. Predicting success of high-flow nasal cannula in pneumonia patients with hypoxemic respiratory failure: the utility of the ROX index. J Crit Care. 2016;35:200-5.

27. Roca O, Caralt B, Messika J, Samper M, Sztrymf B, Hernández $\mathrm{G}$, et al. An index combining respiratory rate and oxygenation to predict outcome of nasal high-flow therapy. Am J Respir Crit Care Med. 2019;199:1368-1376. 